\title{
New Cutoff point of Prostate-Specific Antigen (PSA) and PSA Density (PSAD) to enhance diagnostic specificity for prostate cancer (Pca) in country with low prostate cancer incidence
}

\author{
Djoko Rahardjo, Siti Tersiani Kamil Gardian
}

\begin{abstract}
Abstrak
Tujuan penelitian ini ialah untuk menentukan nilai ambang baru untuk PSA dan PSAD di Indonesia. Telah diteliti 344 penderita dengan keluhan prostat tanpa retensi yang dikonfirmasi dengan biopsi dan/atau pemeriksaan histopatologik. Terdapat 332 (96,5\%) pasien pembesaran prostat jinak dan 12 (3.5\%) pasien kanker prostat. Menggunakan nilai ambang yang diterima secara internasional yaitu $4 \mathrm{ng} / \mathrm{ml}$ dan nilai intermadiet antara 4,1-10 $\mathrm{ng} / \mathrm{ml}$, ditemukan 161 (47\%) pasien dengan nilai PSA kurang atau sama dengan $4 \mathrm{ng} / \mathrm{ml}$ tanpa satu pun penderita kanker, 102 (30\%) pasien dengan nilai 4,1-10 $n g / m l$ dimana hanya ditemukan 1 penderita kanker $(P S A=8,3 ; P S A D=0.21)$; sedangkan 11 dari 81 pasien $(13,6 \%)$ dengan nilai PSA lebih dari $10 \mathrm{ng} / \mathrm{ml}$ menderita kanker. Dengan meningkatkan nilai ambang menjadi $8 \mathrm{ng} / \mathrm{ml}$ dan nilai intermediet menjadi $8.1-30 \mathrm{ng} / \mathrm{m}$, pada kelompok pasien yang sama ditemukan $236(68,6 \%)$ pembesaran prostat jinak masih tanpa ada kanker untuk PSA lebih kecil sama dengan $8 \mathrm{ng} / \mathrm{ml} ; 89$ pembesaran prostat jinak dan I kanker pada nilai intermediet, sedangkan penderita kanker lainnya (11 dari 18 pasien atau 61\%) mempunyai nilai PSA diatas 30 ng/ml. Ditemukan korelasi antara rata-rata nilai $P S A$ dengan usia dan besar prostat $(p<0.01, r=0.242 \& 0.429$ pada nilai $P S A \leq 4.0 \mathrm{ng} / \mathrm{ml} ; r=0.265 \&$ 0.452 pada nilai $P S A \leq 8 \mathrm{ng} / \mathrm{ml}, r=0.261 \& 0.020$ pada $P S A>10 \mathrm{ng} / \mathrm{ml}$ ). Kemampuan nilai ambang baru ini untuk meningkatkan deteksi kanker prostat dievaluasi dengan analisis univariat dan menggunakan kurva Receiving Operating Characteristic (ROC). Dengan nilai ambang baru ini didapatkan sesitivitas $100 \%$ untuk deteksi kanker, sementara spesifisitasnya 85,8\%. Penggunaan nilai PSAD lebih dari 0.20 meningkatkan spesifisitas hingga $94.9 \%$ dan menaikkan kemungkinan deteksi kanker (positive predictive value) dari $12.9 \%$ menjadi 15\%. Area dibawah kurva meningkatkan dari 0.970 menjadi 0.974 untuk PSA dan 0.987 menjadi 0.989 untuk PSAD dibandingkan dengan nilai ambang standar. Dengan nilai ambang baru didapatkan penurunan jumlah biopsi hingga 42.4\% tanpa menghilangkan kemampuan deteksi kanker
\end{abstract}

\begin{abstract}
The purpose of this study is to determine new cutoff point of PSA and PSAD in Indonesia. Three hundred and forty four patients with prostate complain without urinary retention confirmed by biopsies and/or hystopathological examinations were analyzed. There were 332 (96.5\%) patients histologically confirmed benign prostate hyperplasia and $12(3.5 \%)$ had prostate cancer $(P c a)$. Using cutoff level for PSA of $4 \mathrm{ng} / \mathrm{ml}$ and intermediate value of $4.1-10 \mathrm{ng} / \mathrm{ml}$, there were $161(47 \%)$ patients had PSA level less or same as $4 \mathrm{ng} / \mathrm{ml}$ and none of them had Pca, $102(30 \%)$ patients had intermediate PSA level (4.1 to $10 \mathrm{ng} / \mathrm{ml})$ and only I confirmed Pca (PSA 8.3, PSAD 0.21) while 11 from 81 patients (13.6\%) with PSA above $10 \mathrm{ng} / \mathrm{ml} \mathrm{had} \mathrm{Pca.} \mathrm{Raising}$ the cutoff point to $8 \mathrm{ng} / \mathrm{ml}$ and intermediate value of $8.1-30 \mathrm{ng} / \mathrm{ml}$, from the same group of patients we found $236(68.6 \%) \mathrm{BPH}$ patients still with no Pca in PSA less or same as $8.0 \mathrm{ng} / \mathrm{ml} ; 89 \mathrm{BPH}$ patients and I Pca in intermediate PSA level, while the rest Pca patients (11 among 18 or $61 \%$ ) patients) had PSA above $30 \mathrm{ng} / \mathrm{ml}$. We found correlation between mean PSA level with age and prostate volume $(p<0.01, r=0.242 \& 0.429$ in patients with $P S A \leq 4 \mathrm{ng} / \mathrm{ml} ; r=0.265 \& 0.452 \mathrm{in} P S A \leq 8 \mathrm{ng} / \mathrm{ml}$, and $r=0.261$ \& $0.020 \mathrm{in}$ PSA $>10 \mathrm{ng} / \mathrm{ml}$ ). The ability of this new cutoff to enhance the power in detecting Pca was evaluated by using univariate analysis and Receiving Operating Characteristic (ROC) curves. By using new cutoff point produced a sensitivity of $100 \%$ in detecting Pca, while specificity is $85.8 \%$. The application of PSAD greater than 0.20 enhanced the specificity to $94.9 \%$ and increased the possibility, to detect Pca (positive predictive value) from $12.9 \%$ to $15 \%$. Area under the curve has also increased from 0.970 to 0.974 for PSA and 0.987 to 0.989 for PSAD compared with standard cutoff points. With the new cutoff level there was a decrease of the number of biopsies up to $42.4 \%$ without missing any cancer detection
\end{abstract}

Keywords: PSA, PSAD, prostate cancer, new cutoff points, ROC curve

Division of Urology, Department of Surgery, School of Medicine University of IndonesialDr. Cipto Mangunkusumo Hosnital. Jakarta. Indonesia 
Prostate cancer has become the commonest malignancy of the male urinary tract and is the second commonest cancer in Europeans men ${ }^{1}$. In United State it is the first commonest neoplasm in men and second leading cause of cancer death. Data in 1996 revealed that Pca was $40 \%$ from all new malignant diseases in men and it gave $14 \%$ mortality in men due to malignancy ${ }^{2}$. During his life, $20 \%$ of men will have possibility of having Pca. Unlike in western countries, Pca is relatively rare in Indonesia. Although Pca was included in the ten highest malignancy in men, the second most frequent malignancy in urology clinic and it was the most common form of male' cancer, the cases collected between 1990-1994 from different hospitals were only 28-33 per year ${ }^{3}$.

Prostate-specific antigen (PSA) is clinically the most useful tumor marker to detect prostate cancer (Pca) ${ }^{4}$. Combining PSA with PSAD in intermediate serum PSA level, will increase the specificity in Pca detection. PSA is specific for prostate tissue, it is not prostate cancer-specific. An elevated serum value does not always denote prostate cancer.

It has been demonstrated that $1 \mathrm{~g}$ of benign hyperplastic tissue gives rise to $0.2 \mathrm{ng} / \mathrm{ml}$ of PSA in the serum ${ }^{4}$. Even though currently used, PSA alone could not give ideal sensitivity or specificity in screening Pca. Numerous investigators used PSAD, defined as serum PSA level per prostate volume, for those with intermediate serum PSA level. This determinant can help to distinguish men with early Pca from those with BPH only. Despite the vast used of the recommended cutoff level of PSA and PSAD in Pca detection, the appropriate PSA and PSAD cutoff level for Indonesian, as country with low Pca incidence remains unrevealed. Screening modalities and their combination is lack in sufficient specificity resulting in a high ratio between the number of biopsies and the number of positive detected Pca.

In Cipto Mangunkusumo General Central Hospital and Sumber Waras hospital we found mean PSA level of Benign prostate hyperplasia (BPH) patients without urinary retention was still above $4 \mathrm{ng} / \mathrm{ml}$, i.e. 6,8 $\mathrm{ng} / \mathrm{ml}$. While for Pca it was $118.53 \mathrm{ng} / \mathrm{ml}$. Until now the interpretation of PSA value is still controversial. There were some patients with Pca without increasing PSA level, while there were also a lot of patients with $\mathrm{BPH}$ with high PSA value.

The purpose of this study is to know the profile of PSA and PSAD in BPH and Pca patients, to know the correlation in each variable (age, prostate volume, PS and PSAD) and to search for new cutoff point of PSA and PSAD in Indonesia based on the data available in order to enhance diagnostic specificity. Receiving Operating Characteristic (ROC) curves were used to show the relative intrinsic discriminatory potential of various parameters as predictor for a positive biopsy result. The predictors were estimated as a function of the various continuous parameters and of binary parameter, such as PSA and biopsy, by the means of logistic regression analysis. ${ }^{5}$

\section{METHODS}

From September 1994 to August 1997, 344 consecutive patients age 41-90 years who had prostate symptoms without acute urinary retention from Sumber Waras Hospital (private hospital) and Cipto Mangunkusumo General Central Hospital (public hospital) were evaluated. Data collected included age, prostate volume measured by trans rectal ultrasonography, PSA and PSAD, and histopathological examination.

Transrectal ultrasonography was performed using Scanner 200 (Pie Medical, Netherlands) with 7.5 $\mathrm{MHz}$ transducer and the prostate size was measured using the prolate ellipse formula, i.e. prostate volume $\left(\mathrm{cm}^{3}\right)=($ width $\mathrm{x}$ height $\mathrm{x}$ length in $\mathrm{cm}) \times 0.52$. PSA was measured using PSA Enzyme Immunoassay (EIA), IMX PSA Assay Abbott Laboratories, (North Chicago, IL IRMA Count Assay, Diagnostic product, Los Angeles, CA) using PSA monoclonal antibody. PSAD was defined as PSA level per prostate volume $\left(\mathrm{cm}^{3}\right)$. Sextant biopsy using biopsy gun TRUS-guided was performed if malignancy was suspected; as characterized by hard nodule on digital rectal examination, hipoechoic area, PSA level greater than $10 \mathrm{ng} / \mathrm{ml}$, or PSA level $4.1-10 \mathrm{ng} / \mathrm{ml}$ with PSAD greater than 0.15 . Specimen for pathological examinations were sent to Pathology Laboratory in Sumber Waras Hospital or Cipto Mangunkusumo General Central Hospital.

With these original data, analysis was performed to find out new cutoff point of PSA, PSA intermediate and PSAD level. Since the first Pca case revealed with PSA $8.3 \mathrm{ng} / \mathrm{ml}$ and PSAD of 0.21 , we proposed criteria of PSA less or same as $8.0 \mathrm{ng} / \mathrm{ml}$ as no Pca (unnecessary to do biopsy), PSA 8.1 to $30 \mathrm{ng} / \mathrm{ml}$ as an intermediate level, and PSAD above 0.20 as indication for biopsy; and PSA above $30.0 \mathrm{ng} / \mathrm{ml}$ as obligated biopsy. Receiving Operating Characteristic 
(ROC) curves of total serum PSA and PSAD were constructed for all 118 men underwent biopsy with PSA 4.1 to $10 \mathrm{ng} / \mathrm{ml}$ with PSAD above 0.20 and PSA above $10 \mathrm{ng} / \mathrm{ml}$, including 12 patients with Pca. This procedure also constructed for the new cutoff point. ROC curves in which chart the sensitivity versus 1 specificity of the test along a range of cutoff value, were constructed for each PSA group. Sensitivity was defined as equal to the number of true positive divided by the sum of true positive plus false negative. Specificity was defined as equal to the number of true negative divided by the sum of the true negative plus false positive. Positive predictive value was the likelihood of prostate prediction being correct. Points closest to the upper left corner of the graph (100\% sensitivity and 100\% [1-specificity]) provided the best distinction between subject with and without diseases

Statistical analysis of clinical variables, which were age, PSA, prostate volume and PSAD between patients with positive biopsies and negative biopsies were performed using Students t-test. To test correlation between parametric variables, we used Pearson correlation test. For all test probability value $\mathrm{p}<0.01$ was considered statistically significant.

\section{RESULTS}

During the period of 3 years (September 1994-August 1997) we found 344 cases with prostate symptom without urinary retention which consists of $332 \mathrm{BPH}$ patients and 12 Pca patients. Patients were retrieved from both Urology Clinic in Sumber Waras Hospital and Cipto Mangunkusumo General Center Hospital. For diagnostic procedure all of them underwent physical, laboratory (which include PSA), Transrectal ultrasonography (TRUS) and uroflo-metry examinations. Patients' variables were catego-rized into BPH and Pca profile. Table 1 shows comparison of age, prostate volume, PSA and PSAD between $\mathrm{BPH}$ and Pca patients. BPH patient's median age was 65 and the mean was 64.37 while Pca patient's median age was 72.5 and the mean was 73 years old. Prostate volume range in $\mathrm{BPH}$ was 13 to $149 \mathrm{ml}$, while in Pca was 33.9 to $92.5 \mathrm{ml}$. PSA and PSAD were extremely higher in Pca patients compare to $\mathrm{BPH}$ group. We found significant different in all variables between BPH and Pca $(p<0.01)$

Table 1. Profile of Benign Prostate Hyperplasia and Prostate Cancer Patients

\begin{tabular}{lrlrl}
\hline & \multicolumn{2}{c}{ BPH } & \multicolumn{1}{c}{ Pca } \\
& \multicolumn{2}{c}{ Mean \pm SD [range] } & Mean \pm SD [range] \\
& \multicolumn{2}{c}{$\mathrm{N}=332$} & \multicolumn{1}{c}{$\mathrm{N}=12$} \\
\hline Age (years) & $64.37 \pm 8.22$ & {$[41-90]$} & $73.0 \pm 6.08$ & {$[64-85]$} \\
Prostate Volume & $47.44 \pm 23.61$ & {$[13-149]$} & $56.94 \pm 21.21$ & {$[33.9-92.5]$} \\
$(\mathrm{ml})$ & & & & \\
PSA (ng/ml) & $6.78 \pm 7.53$ & {$[0.0-60.6]$} & $118.53 \pm 86.47$ & {$[8.3-298]$} \\
PSAD & $0.15 \pm 0.17$ & {$[0.0-1.27]$} & $2.33 \pm 2.04$ & {$[0.21-7.86]$} \\
\hline
\end{tabular}

* All variables were significantly different $(p<0.01)$, determined by t-te.st

Since the first PSA value of the Pca patient was 8.3 $\mathrm{ng} / \mathrm{ml}$ and PSAD value was 0.21 , we try to use 8 $\mathrm{ng} / \mathrm{ml}$ as a new cutoff level for PSA and $8.1-30 \mathrm{ng} / \mathrm{ml}$ as intermediate level with PSAD of 0.20 as an indication to perform biopsy.

To compare the two cutoff levels, patients were studied using standard and proposed cutoff level (Table 2). Using standard group there were 161 (47\%) cases with PSA level below or same as $4 \mathrm{ng} / \mathrm{ml}, 102$ $(30 \%)$ cases in intermediate range $(4.1-10 \mathrm{ng} / \mathrm{ml})$ and $81(23 \%)$ cases with PSA more than $10 \mathrm{ng} / \mathrm{ml}$. From all the 161 with $P S A \leq 4 \mathrm{ng} / \mathrm{ml}$, there were no prostate biopsy performed and were assumed to be free from cancer based on the digital rectal and TRUS examinations and the result of pathologiccal examinations of the specimen. Prostate biopsy were performed in $34.3 \%$ from 344 patients which were 37 and 81 patients from intermediate PSA level and PSA above $10 \mathrm{ng} / \mathrm{ml}$ respectively (totally 118 biopsies). By these biopsies only 1 case in PSA intermediate level confirmed Pca and 11 cases in PSA above $10 \mathrm{ng} / \mathrm{ml}$ had Pca. 
Table 2. Comparison of Patients profile using standard and proposed PSA cutoff level

\begin{tabular}{l|ccc|ccc}
\hline \multirow{2}{*}{ Variable } & \multicolumn{3}{|c|}{ Standard PSA group (ng/ml) } & \multicolumn{3}{c}{ Prorposed PSA group (ng/ml) } \\
\cline { 2 - 7 } & $\leq 4$ & $4.1-10$ & $>10$ & $\leq 8$ & $8.1-30$ & $>30$ \\
\hline Total cases & $161[47 \%]$ & $102[30 \%]$ & $81[23 \%]$ & $236[69 \%]$ & $90[26 \%]$ & $18[5 \%]$ \\
Mean PSA & $1.99 \pm 0.08^{*}$ & $6.73 \pm 0.17^{*}$ & $32.93 \pm 5.43^{*}$ & $3.24 \pm 0.14^{*}$ & $13.47 \pm 0.50^{*}$ & $94.30 \pm 18.34^{*}$ \\
Mean age & $62 \pm 0.66^{*}$ & $66 \pm 0.74$ & $68 \pm 0.90^{*}$ & $64 \pm 0.53^{*}$ & $67 \pm 0.82$ & $71 \pm 2.07$ \\
Mean volume & $36.50 \pm 1.18^{*}$ & $54.34 \pm 2.49$ & $61.25 \pm 2.86^{*}$ & $41.78 \pm 1.34^{*}$ & $60.69 \pm 2.74$ & $58.57 \pm 5.67$ \\
Mean PSAD & $0.06 \pm 0.003^{*}$ & $0.15 \pm 0.007^{*}$ & $0.64 \pm 0.12^{*}$ & $0.08 \pm 0.004^{*}$ & $0.17 \pm 0.22^{*}$ & $1.86 \pm 0.42^{*}$ \\
No. of Biopsy & 0 & 37 & 81 & 0 & 50 & 18 \\
Prostate Ca & 0 & 1 & 11 & 0 & 1 & 11 \\
BPH & 161 & 101 & 70 & 236 & 89 & 7 \\
\hline
\end{tabular}

* Significance and correlation were determined by $t$-test and Pearson correlation test

The mean age was increased significantly in each PSA subgroup from the standard and proposed PSA group. There were also significance difference and correlation between PSA with age, appeared in PSA less or same as $4.0 \mathrm{ng} / \mathrm{ml}$, PSA less or same as 8.0 $\mathrm{ng} / \mathrm{ml}$ and PSA greater than $10 \mathrm{ng} / \mathrm{ml}(\mathrm{r}=0.242 ; 0.265$ and 0.261 respectively). Other significance difference and correlation were also seen between PSA and prostate volume, in PSA $\leq 4.0 \mathrm{ng} / \mathrm{ml}$ and PSA $\leq 8.0$ $\mathrm{ng} / \mathrm{ml}$. ( $\mathrm{r}=0.429$ and 0.452 ). But between PSA in subgroup greater than $10 \mathrm{ng} / \mathrm{ml}$ and prostate volume we found week correlation $(r=0.020)$. Consequently there was also an increase of PSAD in every subset PSA group $(\mathrm{p}<0.01, \mathrm{r}=0.65 ; 0.43 ; 0.91 ; 0.72 ; 0.57$ and 0.56 respectively) because PSAD was defined as quotient of serum PSA divided with prostate volume.

With new cutoff point, most patients $(69 \%)$ had PSA less or same as $8 \mathrm{ng} / \mathrm{ml}$ and none of them had Pca. In intermediate PSA level $(8.1-30 \mathrm{ng} / \mathrm{ml})$, we found 90 patients, with only 1 patient had Pca. In PSA above 30 ng/ml 11 from 18 patients (61\%) had Pca. There were 50 and 18 biopsies (totally 68 biopsies, table 2 ) in intermediate PSA level with PSAD greater than 0.20 and PSA above $30 \mathrm{ng} / \mathrm{ml}$ respectively. If we used the international cutoff on the new cutoff, there were 25, 75 and 18 biopsies (totally 118 biopsies) in PSA of 8 $\mathrm{ng} / \mathrm{ml} ; 8.1-30 \mathrm{ng} / \mathrm{ml}$ and above $30 \mathrm{ng} / \mathrm{ml}$ (data not showed). The twentyfive biopsies in PSA of $8 \mathrm{ng} / \mathrm{ml}$ becoming zero assumed as no Pca cases, 75 biopsies becoming 50 because of the increase in PSAD (from 0.15 to 0.20 ), the 18 biopsies was stil the same because of the same criteria in performing biopsies. Therefore there would be 50 unnecessary biopsies $(42.4 \%)$ could be saved withourt missing any Pca cases.

By using the new cutoff point produced a sensitivity of $100 \%$ in detecting Pca, and specificity of $85.8 \%$. The application of PSAD greater than 0.20 enhanced the specificity to $94.9 \%$ and increased the possibility to detect Pca (positive predictive value) from $12.9 \%$ to $15 \%$ (Table 3). Area under the curve has also increased from 0.970 to 0.974 for PSA and 0.987 to 0.989 for PSAD compared with standard cutoff points. (Fig. 1) 
Table 3. Sensitivity, specificity and Positive Predictive Value (PPV) for different PSA and PSAD from all patients

\begin{tabular}{|c|c|c|c|c|c|}
\hline & \multirow[t]{2}{*}{ No. Biopsy } & \multirow{2}{*}{$\begin{array}{c}\text { No. Prostate } \\
\text { Cancer }\end{array}$} & \multirow[t]{2}{*}{ PPV } & \multicolumn{2}{|c|}{ Proposed PSA } \\
\hline & & & & Sensitivity & Specificity \\
\hline \multicolumn{6}{|l|}{ PSA (ng/ml) } \\
\hline$\geq 0 \quad(n=344)$ & 118 & 12 & 10.17 & 100 & 0 \\
\hline$>4 \quad(n=183)$ & 118 & 12 & 10.17 & 100 & 58.5 \\
\hline$>8 \quad(n=108)$ & 93 & 12 & 12.90 & 100 & 85.8 \\
\hline$>10(n=81)$ & 80 & 11 & 13.75 & 91.3 & 92.7 \\
\hline$>15(n=48)$ & 48 & 11 & 22.91 & 58 & 99.8 \\
\hline$>20(n=27)$ & 27 & 11 & 40.74 & 37.7 & 99.9 \\
\hline$>25(n=20)$ & 20 & 11 & 55 & 29 & 100 \\
\hline$>30(n=18)$ & 18 & 11 & 61.1 & 24.6 & 100 \\
\hline$>35(n=14)$ & 14 & 11 & 78.57 & 20.3 & 100 \\
\hline$>40(n=12)$ & 12 & 10 & 83.3 & 18.8 & 100 \\
\hline \multicolumn{6}{|l|}{ PSAD } \\
\hline$\geq 0.00$ & 118 & 12 & 10.17 & 100 & 0 \\
\hline$>0.10$ & 118 & 12 & 10.17 & 100 & 64.4 \\
\hline$>0.15$ & 112 & 12 & 10.71 & 100 & 80.7 \\
\hline$>0.20$ & 80 & 12 & 15 & 100 & 94.9 \\
\hline$>0.25$ & 55 & 11 & 20 & 72.5 & 98.2 \\
\hline$>0.30$ & 42 & 11 & 26 & 52.2 & 100 \\
\hline
\end{tabular}

A. PSA (area under the curve 0.971

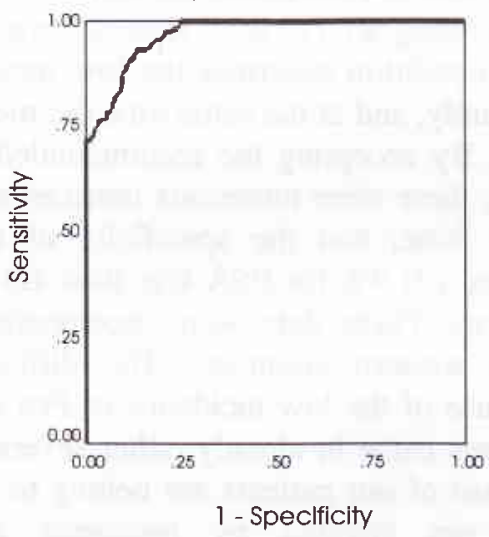

C. PSA (area under the curve 0.9:

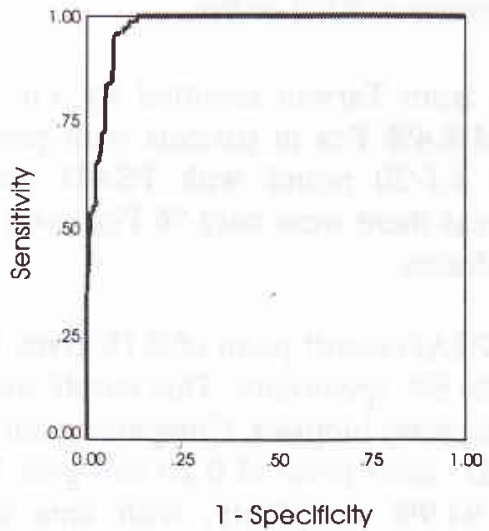

B. PSAD (area under the curve 0.98

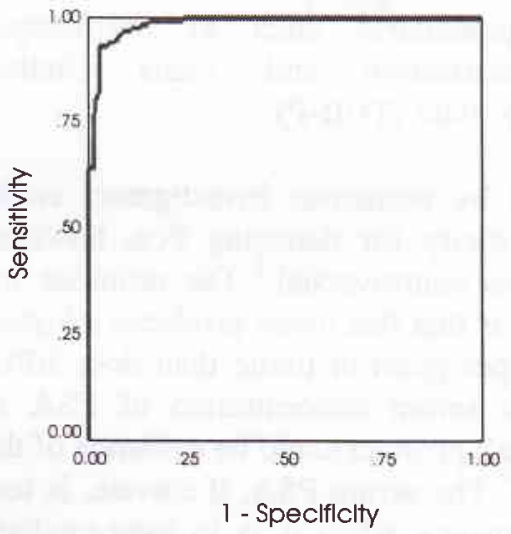

D. PSAD (area under the curve 0.98

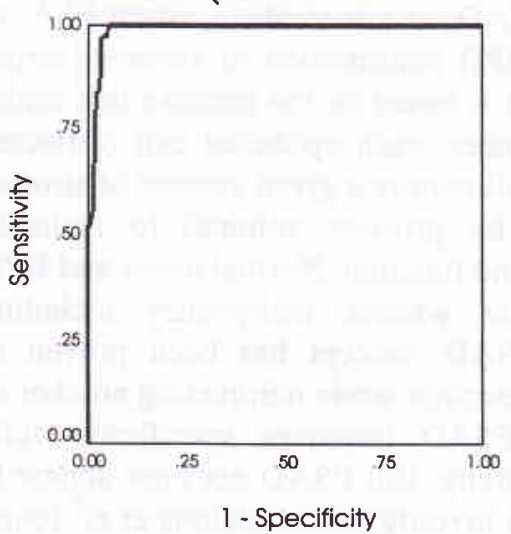

Figure 1. ROC curve for PSA and PSAD for different cutoff-point ( $A$ and $B$ for standard cutoff, $C$ and D for proposed cutoff) 


\section{DISCUSSION}

Prostate-specific antigen is the most tumor specific antigen known. However, it is far from being the ideal tumor marker because PSA is organ specific, not disease specific. ${ }^{2.7}$ To date, serum PSA level is still an important tool for diagnostic screening of prostate cancer. PSA level greater than $4.0 \mathrm{ng} / \mathrm{ml}$ still indicated as a cutoff point to pursue additional diagnostic evaluation to find Pca. Unfortunately, PSA does not appear to have the specificity to distinguish between benign prostate hyperplasia and prostate cancer. There is a difficulty in selecting patients as the candidate of prostate needle biopsy if they clinically show signs and symptoms of BPH with normal consistency of digital rectal examination. As the result, usually there are too many unnecessary biopsies, which can give not only logistic burdens, but also morbidity and psychological problems for the patients. Besides having low specificity, serum PSA could elevate not only in malignancy, but also after DRE procedure, Trans rectal ultrasonography (TRUS), prostate massage, prostatitis and some instrumentation procedures such as cystoscopy, indwelling catheterization and Trans Urethra Resection of the Prostate (TUR-P)

PSAD is thought by numerous investigators could improve the specificity for detecting Pca, however this theory remains controversial. ${ }^{2}$ The rationale for calculating PSAD is that Pca tissue produces a higher serum PSA level per gram of tissue than does BPH. Therefore, a high serum concentration of PSA in patients with a small prostate could be evidence of the present of cancer. ${ }^{8}$ The serum PSA, if elevate, is less specific for malignancy when it is in inter-mediate range of 4.1 to $10 \mathrm{ng} / \mathrm{ml} .^{9}$ Benson et al ${ }^{10}$ developed the concept of PSAD, in intermediate serum PSA, to account for the BPH contribution to elevated serum PSA. The concept is based on the premise that under normal circumstances, each epithelial cell (reflected by serum PSA) will require a given amount of stromal tissue (reflected by prostate volume) to maintain normal structure and function. Normal tissue and BPH adhere to this rule, whereas malignancy, including Pca does not. PSAD concept has been proven to enhance cancer detection while minimizing number of biopsies. Thus, PSAD improves specificity while maintaining sensitivity. But PSAD does not appear to be accepted by all investigators. Catalona et $\mathrm{al}^{8}$ found by using PSAD cutoff 0.15 , as stated in many literatures, enhanced specificity but on the other hand missed half of the tumors. The inaccuracy of the estimation of prostate weight using TRUS compared to actual prsotate weight $(r=0.61)$ become the basic reason of this rejection. So he recommended for needle biopsy in patients with PSA greater than 4.0 $\mathrm{ng} / \mathrm{ml}$. Shinohara et $\mathrm{al}^{6}$ confirmed PSAD was useful in patients with PSA level 4 to $10 \mathrm{ng} / \mathrm{ml}$ with normal DRE and normal ultrasonography. Nevertheless there were $20 \%$ patients had cancer on prostate biopsies. Littrup et al ${ }^{1 /}$ suggested if we use only PSA cutoff 4.0 $\mathrm{ng} / \mathrm{ml}$ as indicator to perform biopsy, it will produce a sensitivity of $67 \%$ and a specificity of $93 \%$. Lowering the cutoff to $2.0 \mathrm{ng} / \mathrm{ml}$, which mean increase the number of biopsy, yielded a sensitivity of $91 \%$ and specificity $71 \%$. Labrie et al $^{12}$ reported similar value: a sensitivity and specificity of $71 \%$ and $91 \%$ for PSA of $4.0 \mathrm{ng} / \mathrm{ml} ; 89 \%$ and $73 \%$ respectively for a PSA of $2.0 \mathrm{ng} / \mathrm{ml}$.

In our series, all Pca patients were detected in serum PSA greater than $4.0 \mathrm{ng} / \mathrm{ml}$. From 102 patients in intermediate PSA level (mean PSA 6.73) only 1 $(0.98 \%)$ Pca was detected with PSAD greater than 0.20 , and in PSA above $10 \mathrm{ng} / \mathrm{ml}$ there were only 11 Pca among 81 (13.6\%) patients (mean PSA 32.93). This condition describes the low incidence of Pca in our study, and at the same time the mean PSA is quite high. By accepting the recommended western cutoff level, there were numerous unnecessary biopsies had been done, and the specificity of this cutoff was limited $(71,9 \%$ for PSA less than $4.0 \mathrm{ng} / \mathrm{ml}$, data not shown). These data were incomparable to the data from western countries. The differences probably because of the low incidence of Pca and most of our patients came in already rather severe conditions due to most of our patients are belong to low-economical and not covered by insurance and were low educational status, and they neglected the initial symptoms of BPH or Pca.

Data from Taiwan reported by Yu and Lai, ${ }^{11}$ they found $8.4 \% \mathrm{Pca}$ in patients with preoperative serum PSA $4.1-20 \mathrm{ng} / \mathrm{ml}$ with PSAD greater than 0.15 whereas there were only $56 \mathrm{Pca}$ cases among 100.000 population.

The PSAD cutoff point of 0.15 gives $100 \%$ sensitivity and $94.5 \%$ specificity. This cutoff would reduce $30 \%$ unnecessary biopsies. Compare to our study, proposed PSAD cutoff point of 0.20 still give $100 \%$ sensitivity and $94.9 \%$ specificity, with area under the curve 0.989 . Hence, it spared $42.4 \%$ unnecessary biopsies without missing any Pca. If we used cutoff value of 0.25 will miss 1 Pca patients $(8.3 \%)$. Gohji et al ${ }^{14}$ had 
a sensitivity of $70 \%$ and a specificity of $67 \%$ for PSAD cutoff 0.18 or greater. Like in Taiwan and Japan in Indonesia Pca incidence were also low. So there were much similarity between the published data and our finding.

Our study showed the mean PSA level in BPH patients was quite high, i.e. $6.78 \pm 7.53$, as well as the mean PSAD, i.e. $0.15 \pm 0.17$. These finding were similar with the Japanese and Taiwanese studies. Their mean PSA were $5.05 \pm 2.15$ for the Japanese and $7.7 \pm 3.1$ for the Taiwanese, while the mean PSAD were 0.17 and 0.27 respectively. While our mean prostate volume $(47.44 \mathrm{cc})$ was bigger than they have, which were $35 \mathrm{cc}$ and $35 \mathrm{cc}$ respectively. The mean age in this study was 64.37 , exactly the same as age referenced PSA published by Mettlin. ${ }^{15}$ For the Pca patients the mean value of PSA, prostate volume and PSAD (118.53 $\pm 86.73 ; \quad 56.94 \pm 21.212 ; \quad 33 \pm 2.04)$ revealed significantly different from the Japanese, the Taiwanese, and western countries. All of the parameters were higher. Once again this condition might be due to the lack of awareness of the diseases. If we take western countries as comparison, Benson et $\mathrm{al}^{\mathrm{e}}$ demonstrated the Pca mean PSA values was only $24.4 \pm 36.9$, the mean of PSAD was $0.581 \pm 0.739$ and the mean of prostate volume was $43.0 \pm 21.6$, whereas for BPH patients, mean of PSA, PSAD and prostate volume were $3.7 \pm 3.3 ; 0.044 \pm 0.027$ and $88.5 \pm 57.2$ respectively. All patients with PSAD greater than 0.12 had Pca. Interestingly, Nishiya et al ${ }^{2}$ from Colorado found mean PSA for BPH and Pca much higher from other western literature i.e. $5.23 \pm 5.04 \mathrm{ng} / \mathrm{ml}$ and $10.39 \pm 11.65 \mathrm{ng} / \mathrm{ml}$ respectively. Djavan et al ${ }^{16}$ also found higher level i.e. $6.72 \pm 1.68$ for mean PSA in $\mathrm{BPH}$ patients, but lower level for mean PSA in Pca patients $(7.45 \pm 1.76)$. He stated cutoff PSAD greater than 0.20 resulted in $57.6 \%$ sensitivity and $80.99 \%$ specificity.

According to our data, mean Pca volume was much bigger than $\mathrm{BPH}$ volume $(56.94+21.21 \mathrm{cc}$ compared to $47.44 \pm 23.61 \mathrm{cc}$ ) This finding is the same as the result of Mettlin et al ${ }^{15}$ which is with $38.9 \pm 16.41$ for mean Pca volume and $33.5 \pm 14.23$ for $\mathrm{BPH}$ volume. But other investigators showed the contradictory. Nishiya found $40.54 \pm 6.56$ mean Pca volume and $42.6 \pm 25.04$ for mean BPH volume. ${ }^{2}$

There were correlations between PSA and age and between PSA and prostate volume in different group of PSA value. PSA increased with age in PSA level $\leq 4.0$ $\mathrm{ng} / \mathrm{ml}, \leq 8.0 \mathrm{ng} / \mathrm{ml}$ and $>10 \mathrm{ng} / \mathrm{ml}(\mathrm{p}<0.01, \mathrm{r}=0.242$;
0.265 and 0.261 receptively, table 2 ). Our finding was not different from Collins ${ }^{17} \quad(\mathrm{p}<0.01, \mathrm{r}=0.37)$ and Oesterling $^{4}(p<0.01$ and $r=0.43)$. Serum PSA was also function of prostate volume. Strong correlation resulted in PSA level $\leq 4.0 \mathrm{ng} / \mathrm{ml}$ and $\leq 8.0 \mathrm{ng} / \mathrm{ml}$ ( $p<0.01$. $r=0.429$ and 0.452 respectively), which is similar to Collins $(p<0.01, r=0.56)$ and Oesterling $(p<0.01$, $r=0.55$ ). The factor most likely to be responsible for the PSA-related increase in age is the concomitant increase in prostate volume as men get older. But between PSA greater than $10 \mathrm{ng} / \mathrm{ml}$ and prostate volume there was week correlation $(r=0.020)$. Between intermediate standard PSA, proposed PSA level and prostate volume there were also week correlation ( $r=0.109 \& 0.124)$. This would seem to indicate a greater diversity in tumor volume and tumor behavior in this subgroup of patients.

Given these condition, the former cutoff level of PSA for $\mathrm{BPH}$ management has lead to too many unnecessary biopsy performed in intermediate PSA level $(4.1$ to $10 \mathrm{ng} / \mathrm{ml})$ with PSAD value greater than 0.15 or in PSA greater than $10 \mathrm{ng} / \mathrm{ml}$.

In summarize, by using the new cutoff to $8.0 \mathrm{ng} / \mathrm{ml}$ we found still no Pca detected in PSA less $8.0 \mathrm{ng} / \mathrm{ml}$ (sensitivity $100 \%$, specificity $85.8 \%$ ). The used of PSAD greater than 0.20 in intermediate PSA level $(8.1$ to $30 \mathrm{ng} / \mathrm{ml}$ ) resulted in $100 \%$ sensitivity and 94.9 specificity. While PSA greater than $30 \mathrm{ng} / \mathrm{ml}$ as upper cutoff resulted in a sensitivity of $24.63 \%$ and a specificity of $100 \%$. With his new recommended cutoff points, we could save up to $42.4 \%$ biopsies without missing any cancer. Further prospective study in hospital-base patients or even more in community based-population with this new cutoff level might lead to better targeting for early detection and also improves this new cutoff performance

\section{REFERENCES}

1. Burton JL, Oakley N, Anderson JB. Recent advances in the histopathology and molecular biology of prostate cancer. $\mathrm{Br} \mathrm{J}$ Urol- in press

2. Nishiya M, Miller G, Lookner DH, Crawford ED. Prostate specific antigen density in patients with histologically proven prostate carcinoma. Cancer 1994;74:3002-9

3. Himawan S, Krisnuhoni E. Urologic cancer in Jakarta: Pathology-based data: 1990-1994. Ind J Onccology 1995;6(2):57-64

4. Oesterling JE, Jacobsen SJ, Chute CG, Guess HA, Girman CJ, Panser LA Lieber MM. Serum prostatespecific antigen in a community-based population of 
healthy men: Establishmen of age-specific references ranges JAMA 1993;270(7):860-4

5. Bangma $\mathrm{CH}$, Rietbergen $\mathrm{BW}$, Kranse R, Blijenberg BG, Peterson K, Schroder FH. The free-to-total prostate specific antigen ratio improves the specivicity ot prostate specific antigen in screening for prostate cancer in general population. J Urol 1997;157:2191-6

6. Shinohara K, Wolf JS, Narayan P, Carrol PR. Comparison of prostate specific antigen with prostate specific antigen density for 3 clinical applications. J Urol 1994;152:1203

7. Benson MC, Whang IS, Pantuck A, Ring K, Kaplan SA, Olsson A, et al. Prostate specific antigen density: a mean of distinguishing benign prostate hypertrophy and prostate cancer. J Urol 1992;147:815-6

8. Catalona WJ, Richie JP, deKernio JB, Ahmann FR, Ratliff TL, Dalkin BL, et al. Comparison of prostate specific antigen concentration versus prostate specific antigen density in the early detection of prostate cancer: Receiver operating characteristic cueves. J Urol $1994 ; 152: 2031-6$

9. Benson MC, Whang IS, Olsson CA, McMahon DJ, Cooner WH. The use of prostate specific density to enhance the predicitive value in intermediate levels of serum prostate specific antigen. J Urol 1992;147:81721

10. Benson MC, Olsson CA. Prostate specific antigen and prostate specific antigen density' roles in patient evaluation and management. Cancer 1994;74:1667-73
11. Yu HJ, Lai MK. The usefulness of prostate specific antigen (PSA) density in patients with intermediate serum PSA level in a country with low incidence of prostate cencer. Urol 1998;51(Suppl 5A):120-30

12. Gohji K, Nomi M, Egawa S, Morisue K, Takenaka A,Oakamoto $\mathrm{M}$ et al. Detection of prostate carcinoma using prostate specific antigen, its density, and the density of transition zone in Japanese men with intermediate serum prostate specific antigen concentration. Cancer 1994;79(10):1969-76

13. Littrup PJ, Goodman AC, Mettlin CJ. The benefit and cost of prostate cancer detection. CA 1993;43:134-8

14. Labrie F, Dupont A, Suburu R, Cusan L, Tremblay M, Gomez JL et al. Serum prostate specific antigen as prescreening test for prostate cancer. J Urol 1992;147:846-5!

15. Mettlin C, Littrup PJ, Kane RA, Murphy GP, Lee F, chesley A. Relative sensitivity and specificity of serum prostate specific antigen (PSA) level compared with age-referenced PSA, PSA density, and PSA change. Cancer 1994;74:1615-20

16. Djavan B, Zlotta AR, Byttebier G, Shariat S, Omar M, Schulman CC, Marberger M. rostate specific antigen density of the transition zone for early detection of prostate cancer. J Urol 1998;160:411-419

17. Collins GN, Lee RJ, McKelvie GB, Rogers CAN, Hehir M. Relationship between prostate specific antigen, prostate volume and age in benign prostate. $\mathrm{Br}$ J Urol 1993;71:445-50 